\title{
Food Security and Farm Household Welfare in Peri- Urban Area of Bantul Regency, Yogyakarta
}

\author{
Triyono \\ Agribusiness Departement \\ Faculty of Agriculture \\ Universitas Muhammadiyah Yogyakarta \\ Yogyakarta, Indonesia \\ triyono@umy.ac.id
}

\author{
Nur Hanifah \\ Agribusiness Departement \\ Faculty of Agriculture \\ Universitas Muhammadiyah Yogyakarta \\ Yogyakarta, Indonesia \\ nurhanifahhanif31@gmail.com
}

\author{
Lestari Rahayu \\ Agribusiness Departement \\ Faculty of Agriculture \\ Universitas Muhammadiyah Yogyakarta \\ Yogyakarta, Indonesia \\ lestari_rahayu@yahoo.com
}

\begin{abstract}
The study aimed to describe rice farm income, its contribution, food security and the welfare of farm households in sub urban. Data were collected by direct interviews with 47 respondents in the sub urban district of Bantul. Technical analysis used was cost and revenue analysis for rice farming, income contribution analysis, analysis of the subsistence level of food, Good Service Ratio analysis and analysis of the purchasing power of farmers. The results showed that the average income of rice farmers in a single growing season in the research location is IDR 3,276,355. The average contribution of rice farming income to total revenue is $\mathbf{2 9 . 8 0 \%}$. Farm households in the research location are classified as food secure with an average value of food security of 1.94. Welfare according to the level of Good Service Ratio of the farm households is relatively more prosperous with a welfare value of 0.66 . Meanwhile, the value of farmers' purchasing power in the research location is equal to $120 \%$, which means that farm households are classified as more prosperous. About $80 \%$ of the farm households in the research location are classified as food secure with an average value of food security of 1.94 .
\end{abstract}

Keywords-Peri-Urban, Food Security, Welfare

\section{INTRODUCTION}

Food is a basic and fundamental requirement for human to survive in life. Food needs seen from the staple food sufficiency in Indonesia, rice is a major source of carbohydrates. A household can be said to meet its food needs when the family members are not hungry, and they can fulfill their food needs. Some experts agree that food security contains at least two basic elements, namely "food security" and "public accessibility" to food material. Although enough food is available at the national and regional levels, if people face inequality in accessing the food needs, then the food security is still low. [1].

Discussing food security is closely related to welfare because food security is one of the main aspects of wellbeing. Household welfare is a condition where people feel comfortable, peaceful, happy, and able to meet their needs. Household welfare with regard to the fulfillment of basic human needs is food, so that household welfare is related to food security. Food security of households (families) can be interpreted as a family's ability to access sufficient food for the life of the family members [2].

In peasant households there are some gaps that impede food security and livelihoods. The main gaps that occur in the agricultural sector are farmland decrease and eroded by urban modernization, especially land which is in peri urban area. Peri urban neighborhood can be defined as region located between rural and urban areas.

Bantul district is geographically adjacent to the region of Yogyakarta municipality. The economic growth and development in Yogyakarta will affect the regions in Bantul. Trading and industrial development that take place in the city of Yogyakarta usually also influence most of Bantul Regency, this of course reduces the productive land for rice farming. The decreasing land area of course leads to a decrease in rice production. It is certainly threatening food security and livelihoods of farmers in the region.

Based on the research results of [3], [4] and [5], the agricultural sector still plays an important role in contributing to the household income of farmers. Revenue from the agricultural sector accounts for $50 \%$ of total household income. Overall agricultural activities have contributed greatly to the total income of farm households. This is because in most of the research locations, farmers still rely on the agricultural sector as their main livelihood. This can be supported by sufficiently available resources such as sufficient land.

Analysis of food security by [3], [6] and [7] suggested that the overall levels of food security in the research locations are relatively steady or surplus. The analysis of the subsistence level of food results show values above 1 so that overall farm households are classified as food secure. This shows that the rice production can fulfil the rice needs of farm households in a single growing season.

The research results of [3] and [8] mentioned that farm households are classified as a prosperous household in terms of food consumption when the proportion is below $50 \%$ of the total expenditure. Conversely, when the proportion of food consumption exceeds $50 \%$ of the total expenditure of farm households, then the households are said to be prosperous. The results showed that the expenditure of the farm households is below $50 \%$, so they are categorized as prosperous. The results of this research study is inversely proportional to [4] and [7] which stated that the total expenditure of farm households is still dominated by spending on food needs, i.e. more than $50 \%$ of the total expenditure. This indicates that people in the study locations are relatively not prosperous.

According to [9] and [5] according to the results of Good Service Ratio, the farm households in the research location are catagorized as prosperous households, evident from the results of GSR analysis > 1 . This means that these 
farm households are able allocate their spending for both food and non-food needs.

Based on the results of the analysis of purchasing power index, [3], [10] and [7] described that the households in their research locations are classified as prosperous. The purchasing power index of the farm households in their locations exceeds the critical value $(100 \%)$, which means that farmer's income is more than their expenses. This indicates that all the farm households in all the research locations are able to meet all their needs, both food and non-food. Inversely proportional to the results of a research by [6] which stated that the household purchasing power is generally in good condition, except in LKDT (upland plateau) in Magelang below 100. This value shows that there is a transfer of consumer goods from other parties to meet the needs of the household.

Based on the description of previous studies, most researchers used the analysis of income and revenue. The analysis was on food security and household welfare associated with farming and industry. Most researchers conducted welfare analysis using a single criterion such as Good Service Ratio, index of purchasing power and exchange rate of farmers. On the other hand, this research on food security and the welfare of farm households in peri urban area of Bantul aimed to describe the revenue analysis, revenue, food security and well-being. The research location was in the peri-urban area of Bantul where the area is very vulnerable to land conversion that may affect the level of food security and household welfare. The analysis of food security used food subsistence level, comparing the production of rice and rice needs equivalent. Meanwhile, the analysis of farm household welfare used two analysis i.e. Good Service Ratio and purchasing power index. These aimed to know the detailed analysis of the welfare of farm households in these regions.

It is therefore important study the level of food security and the welfare of farm households in peri urban area located in Bantul Regency. The objective of this study was to know the income of rice farming, the contribution of rice farming income to the total income of farmers, food security of farm household and welfare of farm households in peri urban area in Bantul.

\section{METHODS}

The method used in this research was descriptive analysis. The research location was selected deliberately or purposively in Banguntapan, Sewon and Kasihan Subdistricts because the three locations are located adjacent to the city of Yogyakarta thus included as peri urban area. The samples were selected using a simple random sampling taken using lottery for the determination of farmers' groups. Having obtained the number of the farmer groups, the number of respondents was then determined using solvin formula as follows:

$$
\mathrm{n}=\frac{\mathrm{N}}{1+\mathrm{N} \mathrm{e}^{2}}
$$

Information:

$\mathrm{n} \quad=$ Number of samples

$\mathrm{N} \quad=$ Number of population

e $\quad=$ Margin of error (in this study $10 \%$ )
The above equation resulted in a total sample of 47 respondents out of a total population of 90 farmers, divided proportionally to the three subdistricts: 13 farmers in Banguntapan, 26 farmers in Sewon and 8 farmers in Kasihan. The data collection was done by direct interviews with the respondents.

To determine the food security and well-being of farm households in the peri urban areas of Bantul, several analysis techniques were done i.e. farming costs, revenue and income, contributions, food security and well-being. These analysis techniques were used to analyze the overall cost incurred in rice farming. Income was calculated by the multiplication of production and product prices. Meanwhile, farm income was calculated from the reduction in total revenue with total cost of farming. According to [5], the contribution of rice farm income to the total farm household income can be analyzed using the following formula:

$$
X=\frac{p 1}{p t} \times 100 \%
$$

Information:

$\mathrm{X}$ : percentage of the contribution of farm income to total farm household income

P1: farm income (IDR)

Pt: total farm household income (IDR)

According to [3], the performance level of household food security of farmers can simply be defined as follows:

$$
\mathrm{TSP}=\frac{\mathrm{PUB}}{\mathrm{KSB}}
$$

Information:

TSP $=$ subsistence level of food (TSP $=1$ subsistence, $\mathrm{TSP}>$ 1 surplus, TSP $<1$ deficit)

$\mathrm{PUB}=$ production of paddy (rice)

$\mathrm{KSB}=$ rice needs equivalent

While [9] adds an indicator to analyze the level of welfare of farmers in general that is the formula of Good Service Ratio (GSR). Good Service Ratio is the ratio of food consumption expenditure by non-food consumption expenditures. To determine the level of household welfare is measured using Good Service Ratio (GSR) with the following formula:

$$
\mathrm{GSR}=\frac{\text { Food expenditure }}{\text { Non Food Expenditure }}
$$

Information:

GSR $>1$ means that the household economy is less prosperous

$\mathrm{GSR}=1$ means that the household economy is prosperous GSR $<1$ means that the household economy is more prosperous

According to [6], the formula of farm households' purchasing power (DBPp) is as follows:

$$
\mathrm{DBP}_{\mathrm{p}}=\frac{\mathrm{TP}}{\mathrm{TEPfol}}
$$

Where:

DBPp $=$ The purchasing power of farm households

$\mathrm{TP}=$ Total income of farm households (IDR / year) from all sources

TE = Total expenditure of farm households (IDR / year)

$\mathrm{BU}=$ The cost of farming 


\section{RESULTS AND DISCUSSION}

\section{A. Cost, Revenue and Income of Rice Farm}

An analysis of income was from the deduction of farm revenue by the total cost. Total costs incurred in rice farming in the peri-urban area in Bantul Regency were all thereal costs incurred in farming. Revenue was calculated by the multiplication of farm production in the forms of rice production and prices.

From table 1 it can be seen that the biggest total cost occurs in Banguntapan Subdistrict because the farmers in this region spend much for production facilities, such as using hybrid rice seeds which are relatively expensive. In terms of labor, the farmers in this subdistrict hire people outside their family members in all the farming activities. Farmers in this region also use sharecropping system so that the their mischellaneous expenses are quite much. These are the reasons why the total cost of this subdistrict is higher than those of the other subdistricts. Total costs associated with the production of rice produced by farmers.

Table 1. Farm Cost and Income

\begin{tabular}{|c|c|c|c|c|}
\hline Commentary & $\begin{array}{c}\text { Banguntapa } \\
\text { n } \\
\mathbf{3 , 0 5 0} \mathrm{m} 2\end{array}$ & $\begin{array}{c}\text { Sewon } \\
2,075 \mathrm{~m} 2\end{array}$ & $\begin{array}{c}\text { Kasihan } \\
2,114 \text { m2 }\end{array}$ & Average \\
\hline Input Cost & 890,312 & 537,392 & 365,115 & 605,684 \\
\hline Labor costs & $1,928,077$ & 757,423 & $1,036,750$ & $1,128,766$ \\
\hline $\begin{array}{l}\text { Tool } \\
\text { Depreciation } \\
\text { costs }\end{array}$ & 62,435 & 52,713 & 53,076 & 55,464 \\
\hline $\begin{array}{l}\text { Miscellaneou } \\
\text { s expense }\end{array}$ & $2,919,538$ & $1,560,603$ & $1,097,833$ & $1,857,709$ \\
\hline Total cost & $5,800,362$ & $2,908,131$ & $2,552,775$ & $3,647,624$ \\
\hline $\begin{array}{l}\text { Production } \\
\text { (kg) }\end{array}$ & 923.08 & 565.38 & 508.75 & 654.68 \\
\hline Price (IDR) & 10,651 & 10,689 & 9,949 & 10,576 \\
\hline Revenue & 9,831,538 & $6,043,269$ & $5,061,500$ & $6,923,979$ \\
\hline Income & $4,031,176$ & $3,135,138$ & $2,508,725$ & $3,276,355$ \\
\hline
\end{tabular}

Overall the highest rice production is in Banguntapan Subdistrict because this subdistrict has sufficient land so that the rice production is higher than those of other subdistricts. In terms of the data related to food crops harvested area in peri-urban area of Bantul, Banguntapan Subdistrict has the largest rice harvested area compared to other regions so it is understandable why the rice production in this subdistrict is higher than those of other subdistricts.

Rice production is related to income, the higher the production the higher the income. Although farming costs incurred by farmers in Banguntapan Subdistrict is high, the rice production of this subdistrict is also high, resulting in a higher farming income in Banguntapan Subdistrict compared to other subdistricts.

\section{B. Rice Revenue}

The contribution of income is used to find out about the percentage of rice farming income contribution to the total income of farm households in one year.

The largest contribution is in Sewon Subdistrict (Table 2 ). Rice farming income in this subdistrict contributes $37.66 \%$ of the total farm household income. Although the overall contribution of farm income in the peri-urban area in Bantul Regency tends to be small, rice farming plays a major role in meeting the needs for staple food such as rice as the main carbohydrate source. This is inversely proportional to a research by [8] which explains that the contributions of rice farming income to the total income in his research locations are $93.05 \%$ and $84.07 \%$. Such percentages indicate that the activities and occupations in the research locations are dominantly as local rice farmers.

Table 2. Revenue of Rice Farming

\begin{tabular}{|c|c|c|c|c|}
\hline \multicolumn{5}{|c|}{ Revenue } \\
\hline & Banguntapan & Sewon & Kasihan & Average \\
\hline Rice revenueUT & $4,031,177$ & $3,135,138$ & $2,508,725$ & $3,276,355$ \\
\hline Revenue on farm & 461,538 & 446,154 & $1,000,000$ & 544,681 \\
\hline Off-farm income & $1,561,538$ & 607,692 & - & 768,085 \\
\hline $\begin{array}{l}\text { Non-farm } \\
\text { income }\end{array}$ & $8,400,000$ & $4,136,154$ & $10,533,333$ & $6,404,397$ \\
\hline $\begin{array}{l}\text { Total Revenue } \\
\text { RT }\end{array}$ & $14,454,254$ & $8,325,138$ & $14,042,059$ & $10,993,518$ \\
\hline $\begin{array}{l}\text { Contribution } \\
(\%)\end{array}$ & 27.89 & 37.66 & 17.87 & 29.80 \\
\hline
\end{tabular}

\section{Food Security (Subsistence Level of Food)}

Food security is analyzed using the subsistence level of food that is by comparing rice production with rice needs equivalent. Food security (food subsistence level) is used to determine the rice production capability of rice farming in meeting the rice neeeds equivalent of farm households.

Food security (food subsistence level) of farm households in the peri-urban area of Bantul is classified as food secure. The average food subsistence level of farm households in the peri-urban area of Bantul is classified as surplus, reaching 1.94 (Table 3). This means that the production of rice in the regions is able to meet the rice needs equivalent of the population in these regions, making them fall in the category of food secure. The results are consistent with a research by [7] which showed that the food security level of farm households in Galeh watershed, Semarang Regency is relatively steady, or in the criteria surplus reaching 1.27 .

In line with a research by [3], which revealed that the farm household food security in their study locations is quite high because the food subsistence value is greater than 1. This shows that the total farm household income in the study locations is surplus. In line with a research by [6] which states that the food security in their research locations is relatively stable, evident by the overall value of the food subsistence in their research locations which is greater than 1. Their research locations are classified as food secure because the rice production is able to meet the household food consumption.

According to [11], food security can be calculated from an analysis of household dietary diversity score, food consumption score and availability of hygienic food per capita. From the analysis, it can be seen that the households who are small-scale irrigation project beneficiaries are much more food secure than households who are not.

The consumption patterns of farm households in rural and low-income households in general tend to be relatively 
simple. Rice is still a staple food in this group although they still consume other carbohydrate source foods such as corn, tubers and noodles (flour). The food expenditure is dominated by expenditure on source of carbohydrate. Therefore, carbohydrate sources have a high contribution to energy consumption. The food security status can be seen from the adequacy of source of carbohydrate consumption, in this case rice consumption [12].

Food security is related to improvement of the welfare of farmers. To ensure food security by increasing national food supply, especially rice, both long and short-term policies are needed. An example of short-term policies is farmer protection by agricultural product import restriction. Meanwhile, a long-term policy is to increase domestic production as well as increase local food security [13].

Table 3. Food Security (Subsistence Level of Food)

\begin{tabular}{lrrrr}
\hline \multicolumn{5}{c}{ Food Security (Subsistence Level of Food) } \\
\hline & Banguntapan & \multicolumn{1}{c}{ Sewon } & Kasihan & Average \\
\hline $\begin{array}{l}\text { Rice Production } \\
\text { (Kg) }\end{array}$ & 697.62 & 418.38 & 425.00 & 496.74 \\
$\begin{array}{l}\text { Rice needs } \\
\text { equivalent }\end{array}$ & 282.16 & 222.55 & 319.77 & 255.59 \\
Resilience (TSP) & 2.47 & 1.88 & 1.37 & 1.94 \\
\hline
\end{tabular}

Table 4. Farm Household Expenditure Structure

\begin{tabular}{lrrrr} 
& \multicolumn{3}{c}{ Household expenditure (IDR) } & Average \\
\cline { 2 - 5 } & Banguntapan & Sewon & Kasihan & \\
\hline $\begin{array}{l}\text { Food } \\
\text { expenditure }\end{array}$ & $3,912,169$ & $3,424,819$ & $4,022,375$ & $3,661,330$ \\
\hline $\begin{array}{l}\text { Non-food } \\
\text { expenditure }\end{array}$ & $5,983,897$ & $4,316,897$ & $8,618,792$ & $5,510,220$ \\
\hline $\begin{array}{l}\text { Total } \\
\text { Expenditure }\end{array}$ & $\mathbf{9 , 8 9 6 , 0 6 6}$ & $\mathbf{7 , 7 4 1 , 7 1 6}$ & $\mathbf{1 2 , 6 4 1 , 1 6 7}$ & $\mathbf{9 , 1 7 1 , 5 5 0}$ \\
\hline
\end{tabular}

\section{Farm Household Expenditure Structure}

Household expenditure is an overall expenditure made by farm households to meet their life needs. Household expenditure is divided into food and non-food expenditures.

Farm household expenditure is categorized in food expenditures and non-food expenditures. The overall nonfood expenditure of farm households in the peri-urban areas of Bantul is greater than the food expenditures (Table 4). This indicates that farmers in the peri-urban areas of Bantul can allocate their household income not only to meet their food needs, but also to meet their non-food needs. The results of a study by [8] showed that farm households are categorized as prosperous if the expenditure for food consumption is below $50 \%$ of the total household consumption expenditure. On the other hand, if the food consumption expenditure exceeds 50\%, then the households are less prosperous. The results of a study by [14] showed that households with a higher welfare level is able to meet both their food and non food needs. This is as applicable in Engel's law, explaining that the proportion of income spent on food falls when income rises. According to [15], the determinants of food expenditure of households are land conversion and assets, where both of these variables have negative effect. Households who do not undergo land conversion have lower food expenditure compared to households who undergo land conversion. The higher the asset value, the lower the food expenditure. Findings on assets have negative effect as stated by Engel's law, i.e. the higher the wealth, the lower the food expenditure.

\section{E. Farmers welfare}

Welfare analysis was used to determine the level of farm household welfare in the peri-urban area of Bantul, which was analyzed by using Good Service Ratio formula and the purchasing power of farmers. Good Service Ratio analysis is a comparison of food expenditure and non-food expenditures. Analysis of purchasing power is the ratio of total income to total expenditure and multiplied by $100 \%$.

Table 5. Farm Household Welfare

\begin{tabular}{lrrrr} 
Expenditure & Banguntapan & Sewon & Kasihan & Average \\
\hline \multicolumn{5}{c}{ Good Service Ratio } \\
Food & $3,912,169$ & $3,424,819$ & $4,022,375$ & $3,661,330$ \\
Non food & $5,983,897$ & $4,316,897$ & $8,618,792$ & $5,510,220$ \\
GSR & 0.65 & 0.79 & 0.47 & 0.66 \\
\hline \multicolumn{5}{c}{ Purchasing Power Index } \\
Total income & $14,454,254$ & $8,325,138$ & 14.042 .059 & $10,993,518$ \\
Total & $9,896,067$ & $7,741,717$ & 12.641 .167 & $9,171,550$ \\
Expenditure & 146 & 108 & 111 & 120 \\
Welfare $(\%)$ & \multicolumn{5}{c}{10} \\
\hline
\end{tabular}

According to Good Service Ratio analysis, farm households can be categorized as prosperous if the value of GSR $<1$. The average value of GSR in the peri-urban area of Bantul is 0.66 so that the farm households in the regions can be said to be more prosperous (Table 5). The overall non-food expenditure of the farm households in the region is greater than the food expenditures. This means that the farmer income both from rice farming and non-rice farming is able to meet their food needs as well as non-food needs.

In line with a research by [9], the welfare of farm households can be calculated by using GSR (Good Service Ratio), that is the ratio between food consumption expenditure by non-food expenditures. The results of a research by [5] explain that in household economy, the calculation of household income and expenditure can be used to reflect the level of welfare. If the GSR value is less than 1 then it should be considered more prosperous. If the GSR value is equal to 1 , the farm households are considered prosperous. If the GSR value is greater than 1, then the farm household is considered less prosperous.

Overall, the analysis of the welfare in terms of farmers' purchasing power in the three sub-districts in Bantul showed a value greater than the critical value, i.e. $120 \%$. This means that the whole farm households in these subdistricts are in normal and stable economic condition, as evidenced by the fact that farmers are able to meet their food and non-food needs from their total income. Even they still have remaining income of $20 \%$ which can be used for savings. 
This is in line with a research by [7] which showed that the purchasing power of farm households in Galeh watershed is greater than the critical value of $100 \%$, i.e. reaching $116.30 \%$. This shows that all the farm households in Galeh watershed are in normal and stable economic condition, where they are able to meet their food and nonfood needs, and they still have remaining incomeof $16.3 \%$ which can be used for savings. According to [8], the level of household consumption expenditure has a positive correlation with the level of income.

The results of a research by [10] explain that the analysis of the purchasing power of farm households could serve as an indicator of the economic welfare of farmers. The higher the level of purchasing power, the better the access of farmers to food, the better the level of household food security. The higher the purchasing power of a household, the higher the level of farm household welfare. This is in line with a research of [6], that purchasing power is calculated from the comparison of total income to total expenditure then multiplied by $100 \%$.

The results of a research of [16] showed that food commodities should be developed, and the main commodities are rice, maize and cassava. In developing the main food commodities, it is necessary to implement priority strategies, namely the utilization of Appropriate Technology Service Post (Posyantek). This strategy is expected to increase the productivity of food crops, thus supporting the food security of an area, particularly the food security in Batang Regency.

\section{CONCLUSION}

The income of rice farmers in the peri-urban areas of Bantul classified as agricultural land varies widely. The average income of rice farmers is IDR 3,276,355. This has a relatively small contribution to the total farm household income i.e. only $29.80 \%$.

The food security in the research locations is classified as surplus, seen from the security value of 1.94 or $>1$. In terms of good service ratio, the farm households in the research locations are relatively more prosperous with a value of 0.66 . Similarly, based on the analysis of the purchasing power, the farm households in the research locations are relatively prosperous with a value of $120 \%$.

It is expected that rice farmers in the peri-urban area of Bantul maintain their agricultural land as paddy field. It is necessary for government to take decisive actions regarding rice field land conversion in the peri-urban areas of Bantul Regency.

\section{REFERENCES}

[1] Arifin, B. 2001. Assessing Sprektrum Indonesian Agricultural Policy Structure, Case and Alternative Strategies. Publisher, Jakarta.

[2] Sunarti, E. \& A. Khomsan. 2012. Family Welfare farmer why difficult to realize? (On line) http://euissunarti.staff.ipb.ac.id/files/2012/03/Dr.-Ir.-Euis-SunartiKesejahteraan-Keluarga-Petani.pdf accessed on December 31, 2017

[3] Sadikin. I \& Subagyono. K. 2008. Performance Indicators Rural Welfare of Farmers Rice in Karawang, 2008. Proceedings of the National Seminar. BPTP West Java, Bandung Barat

[4] Burhansyah R. \& Melia. 2009. Performance Indicators Rice and Welfare of Farmers in Rice Production Centers Kubu Raya.
Proceedings of the National Seminar. BPTP Kalimantan Barat, Pontianak

[5] Rohmah W, Suryantini A, Hartono, S. 2014. Analysis of Income and Household Welfare Sugar Cane Growers Planting and keprasan in Bantul. Agro Eco. Vol. 24, No. 1, 2014

[6] Bachelor \& Munir. 2008. Analysis Farmer Household Income Viewed from the aspect of the Rural Economic Development Indicators. Proceedings of the National Seminar. BPTP Central Java, Central Java.

[7] Rifai A, Supardi S, Hastuti D. Household Food Security 2012. Farmers Watershed (DAS) Galeh Semarang regency. J. Agri Scien Vol 8 No 1,2012

[8] Wardhie, J. 2015. Revenue Analysis of Local Rice Farmers Welfare and Tidal Land in Kapuas. Agros J. Vol. 17 No. 2, 2015

[9] Wicaksono, KW; Suratiyah, K; Waluyati, LR 2013. Domestic Industry Tempe Role In Fighting Poverty in Rural Poncosari Srandakan Bantul. Agro Eco Vol 24, No. 2, 2013

[10] Alfrida .A \& Noor .IT 2017. Revenue Analysis and Welfare Rice Farmer Households Based on Land. Students Imliah AGROINFO GALUH J. Vol 4 No. 3.2017

[11] Mengesha, SD 2017. Food Security Status of Peri-Urban Modern Small Scale Irrigation Project Beneficiary Female Headed Households in Kobo Town, Ethiopia. J. Food Sec Vol 5 No. 6, 2017

[12] Concerned SD, SS Hariadi, Mudiyono. 2012. Food Security Threat Farmer Households. CIVIS Scientific J. Vol 2 No. 2, 2012

[13] Prabowo, R. 2010. Government Policies In Achieving Food Security in Indonesia, J. Agri Scien Vol 6 No. 2, 2010

[14] Amaliyah, H. 2011. Analysis of Relationship Proportion of Expenditure and Food Consumption by Food Security Rice Farmer Households in Klaten District. Essay. Faculty of Agriculture, University of March Surakarta. Central Java.

[15] Purwaningsih Y, Sutomo, Istiqomah N. 2015. Impact Statement Against Land Transfer Function Level Household Food Security Farmers in Karanganyar, Central Java. J. Agri Vol 1 No. 2, 2015.

[16] Wijaya, O. 2017. Food Commodities Commodity Development Strategy in Support of Food Security Areas (Case Study in Batang, Central Java Province). J. Agri and Rur Dev Res Vol 3 No. 1, 2 